\title{
Juozas Baltušis ir Eduardas Mieželaitis tautinio atgimimo ir pirmaisiais Lietuvos nepriklausomybės metais
}

\author{
MINDAUGAS TAMOŠAITIS \\ Lietuvos edukologijos universitetas, Istorijos fakultetas, Lietuvos istorijos katedra, T. Ševčenkos g. 31, LT-03111 Vilnius \\ El. paštas mindaugas.tamosaitis@leu.lt
}

\begin{abstract}
Straipsnyje išskirtinis demesys skiriamas Lietuvos SSR rašytojų ir politinio elito atstovų Juozo Baltušio ir Eduardo Mieželaičio, visuomenèje sulaukusių prieštaringo vertinimo, užimtai pozicijai tautinio atgimimo ir pirmaisiais Lietuvos nepriklausomybès metais. Nagrinėjama, kaip ir kodèl šios asmenybès istorinio lūžio laikotarpiu vertino prasidejusias permainas šalyje, nepriklausomos Lietuvos pirmuosius metus. Mèginama J. Baltušį sąlyginai palyginti su norvegų rašytoju Knutu Hamsunu, taip pat paaiškinti, kodèl E. Mieželaitis atkurtoje nepriklausomoje Lietuvoje save laikẻ "nereikalingu žmogumi“.
\end{abstract}

Raktažodžiai: J. Baltušis, E. Mieželaitis, Lietuvos komunistų partija (LKP), tautinis atgimimas, Sąūdis, Lietuvos nepriklausomybè, valdžia, opozicija

\section{IVADAS}

Lietuvos SSR kelių dešimtmečių literatūra neatsiejama nuo rašytojų klasikų Juozo Baltušio (1909-1991) ir Eduardo Mieželaičio (1919-1997). Pirmasis vyresnès kartos visuomenei puikiai žinomas dèl savo gausybès literatūrinių kūrinių, tokių kaip Gieda gaideliai, Parduotos vasaros, Su kuo valgyta druska, Sakmé apie Juza ir kt.; antrasis, be gausybès savo daugiausiai poezijos knygų, visoje SSRS išgarsèjo 1962 m., kai už eilèraščių ciklą Žmogus gavo pačią solidžiausią Lenino premiją. (Sigito Gedos teigimu, visuotinis E. Mieželaičio „garbstymas, jo Žmogaus visasajunginis kultas savaime, nejučiomis ittikino ji patį, kad tai yra be galo didelis ir reikšmingas kūrinys. Toks poeto ir jo kūrybos sureikšminimas nẻ vienam neišeina í gerą“ $[21,226]$.) J. Baltušio ir E. Mieželaičio išleistos knygos buvo plačiai skaitomos, patys jų autoriai savo kūrinius vaizdžiai kaip „žodžio meistrai“ (anot J. Baltušio, „niekad nesu sakęs kalbų, iš anksto pasirašytų popieriuje, šnekejjau visuomet iš širdies ir, kaip sakoma, iš galvos. Kitokio metodo nepripažinau niekad“) [11, 261] pristatydavo dažnuose susitikimuose su gausiais savo kūrybos gerbejjais, taip pat skaitant kūrinių ištraukas radijo ir televizijos laidose. Sovietmečiu literatūra LSSR gyventojams tiesiog būdavo neịsivaizduojama be jų numylètinių J. Baltušio ir E. Mieželaičio, kurie (J. Baltušis stalinizmo metais savo veiksmais net tiesiogiai prisidèjo prie susidorojimo su ị valdžios nemalonę patekusiais 
rašytojais) (1) būdami komunistų partijos nariai ir užimdami politinius postus priklausé LSSR politiniam elitui: J. Baltušis 1958-1975 m. buvo kandidatas ị Lietuvos komunistų partijos (LKP) centro komiteto (CK) narius, 1947-1975 m., 1980-1990 m. - Lietuvos SSR Aukščiausiosios Tarybos (AT), 1959-1967 m. - AT Prezidiumo pirmininko pavaduotojas; E. Mieželaitis 1960-1989 m. priklausė LKP CK, 1955-1963 m., 1962-1970 m. buvo SSRS AT deputatas, 1975-1989 m. - Lietuvos SSR AT deputatas, 1975-1989 m. - LSSR AT Prezidiumo pirmininko pavaduotojas. Dèl savo charizmos, svorio visuomenèje ir užimamų pareigų J. Baltušiui ir E. Mieželaičiui sovietmečiu pavyko išlikti dėmesio centre, o daliai visuomenès - net savo laikmečio herojais ar net jo simboliais.

Tautinio atgimimo laikotarpiu ir pirmaisiais nepriklausomybės metais pasikeitus politinei situacijai J. Baltušis ir E. Mieželaitis išgyveno sunkius laikus. Anot fotografo Antano Sutkaus, naujasis Lietuvos laikotarpis sutapo su E. Mieželaičio (tą patį galima pasakyti ir apie J. Baltušs - M. T.) gyvenimo saulèlydžiu: „Taip, jo karta buvo komunistinių laikų. O ką ta karta tuo komunistiniu laiku darè - nerūpejjo niekam. Nurašyti mes buvom visi“ [21, 36-84]. Todèl E. Mieželaitis pertvarkos metais save laikė „nereikalingu žmogumi“, o J. Baltušis, viešai išsakęs savo kitokią nuomonę dèl Lietuvos nepriklausomybės, sulaukẻ savo tèvynainių didelès kritikos.

Kadangi istoriografijoje J. Baltušio bei E. Mieželaičio užimtos pozicijos tautinio atgimimo ir pirmaisiais Lietuvos nepriklausomybès metais atskiro tyrimo nesulaukè (tyrèjai daugiau dèmesio skiria šių asmenybių veiklai sovietmečiu) (2), nuspręsta parengti šią publikaciją.

Straipsnio tikslas - išnagrinèti rašytojų J. Baltušio ir E. Mieželaičio užimtą poziciją tautinio atgimimo ir pirmaisiais Lietuvos nepriklausomybės metais. Tikslui pasiekti keliami šie uždaviniai: įvertinti J. Baltušio veiksmus ir Lietuvos visuomenés požiūrị ị ši rašytoją apariamuoju laikotarpiu; atskleisti E. Mieželaičio požiūrị ị to meto aprašomus ịvykius.

Straipsnis parengtas remiantis J. Baltušio publikuota korespondencija, amžininkų atsiminimais, to meto spauda. Daug informacijos rasta E. Mieželaičio spaudoje paskelbtame dienoraštyje ir po jo mirties išleistoje autobiografinėje knygoje Nereikalingas žmogus, kurios paskirtị autorius ịvardijo taip: „Nerašau šios knygos niekam kitam, nerašau jos net skaitytojui, kurio nematau dabar ir neịsivaizduoju ateity, rašau sau pačiam, kaip pats gyvenimas ir sunkūs, skaudūs, dramatiški išgyvenimai privedè mane prie humanistinio „Žmogaus“ ir jo „Antipodo“ - taigi iki „Mitų“ koncepcijos“ [19, 10].

\section{VIENAS PRIEŠ SROVĘ: JUOZO BALTUŠIO POZICIJA}

Prasidejus tautiniam atgimimui ir spartiems pertvarkymams, Lietuvos visuomenei labai buvo svarbi jos autoritetų užimta pozicija. Bundanti lietuvių tauta susižavejjusi, ausis ištempusi daugiatūkstantiniuose mitinguose klausėsi Justino Marcinkevičiaus ir kitų jos pripažintų rašytojų kalbų. Daug vilčių dèta ị J. Baltušị, tačiau jis ne tik kad nepasirode Sąjūdžio mitinguose, bet ir kitu būdu bei kitur išsakè savo atskirą nuomonę visai Lietuvai opiais klausimais. Ši kartą beveik aštuoniasdešimtmetis klasikas („Baltušis buvo itin komunikabilus, mokejjo bendrauti

(1) Išsamiau apie J. Baltušio ir jo aplinkos rašytojų veiklą pokariu žr. Tamošaitis, Mindaugas. Skausmingas praregejimas. Lietuvių rašytojai Antrojo pasaulinio karo metais ir pokariu. Vilnius: Gimtasis žodis, 2014.

(2) Pvz., Ivanauskas, Vilius. Sovietinis režimas ir kultūrinès nomenklatūros kaita vèlyvuoju sovietmečiu Lietuvoje. Rašytojų aplinkos atvejis. Politologija, 2010, Nr. 4, p. 53-84; Baliutytė, Elena. (Ki)toks Mieželaitis: kas likę „Žmogaus“ šešèly? Prieiga per internetą: http://literaturairmenas.lt/2014-1003-nr-3490/2029-literatura/3205-elena-baliutyte-ki-toks-miezelaitis-kas-like-zmogaus-sesely [žr. $20151108]$. 
su net labai skirtingos aplinkos ir išsilavinimo žmonèmis“) [3, 10] dèmesio sulaukè dèl to, kad prieštaringai vertino Sąjūdžio veiklą ir prasidejjusias didžiąsias permainas. Iš pradžių jis 1988 m. rudeni kaip LSSR AT deputatas (taip elgèsi deputatai rašytojai J. Marcinkevičius, J. Nekrošius) siūlè tautinę vèliavą patvirtinti valstybe LSSR vèliava, o „Tautišką giesmę“ - LSSR valstybės himnu, LSSR herbu patvirtinti vytị ir padaryti atitinkamus ịrašus LSSR konstitucijoje [30, 2-3]. Tokie veiksmai atspindèjo anuometinius tautos lūkesčius. Tačiau J. Baltušis, remdamas pertvarką ir siekdamas žmonėms geresnių gyvenimo sąlygų, pasisakẻ prieš Lietuvos nepriklausomybès atkūrimo idèją. 1989 m. kovo 6 d. LSSR Rašytojų sąungos pirminès partinès organizacijos susirinkime, skirtame LKP CK XVII plenumui, J. Baltušis, priminęs, jog jis 7 metus gyveno „po caro vèliava“, 20 metų - „po Smetonos vèliava“, 40 metų - „po raudona vèliava, dabar vèl pastatè trispalvę“, pareiškè, kad esmé - ne vèliavų spalvos. Esą ne vèliavos lemia tautų ir žmonių likimą, ir ne taip svarbu, kokios charakteristikos jam klijuojamos. J. Baltušis, pripažinęs, jog yra ne prieš Sąjūdị („ne kartą esu jị užtaręs už naują mąstyseną, ekonomikos trūkumų, ekologinès krašto padèties kritiką. Tarp jų [sąjūdiečių - M. T.] yra dorų žmonių“), nepritarẻ Sąjūdžio pastangoms atkurti iki 1940 m. buvusią Lietuvą. J. Baltušiui ta Lietuva siejosi su sunkiais išgyvenimais (kurị laiką jam teko bernauti), „klasiniu susiskirstymu“, „fašistiniu perversmu“ (turimas omenyje 1926 m. gruodžio 17 d. Lietuvoje karininkų ivvykdytas valstybès perversmas, kai ị valdžią atėjo Antanas Smetona; jo valdymas, trukęs iki 1940 m. vidurio, sovietmečiu buvo vadinamas fašistiniu, nors tuo metu Lietuvoje fašizmo nebuvo, nebuvo ir demokratijos), valstiečių ūkių pardavinėjimu iš varžytinių, bėgimu nuo skurdo ị užsienị (iš tiesų 1920-1940 m. iš Lietuvos emigravo per 102 tūkst. gyventojų). J. Baltušis negalèjo susitaikyti su stalinizmu („tuo metu stalinistinès tragedijos niekas nesitikèjo“), brežnevizmu. Jam norejjosi „geresnès, pažangesnès Lietuvos“, kad „Lietuva surastų tikrą ir teisingą kelią. Visa Lietuva - su Klaipėdos kraštu, Vilnium“ [10, 208]. 1989 m. rudenị LSSR AT deputatui J. Baltušiui, jo žodžiais tariant, labiausiai slègè širdị visuomenėje aiškiai prasidèjęs ir nesulaikomai besiplètojantis susiskaldymas ị sąjūdžius ir sąūdèlius, organizuojamas partijas, vienybės tarp LSSR AT deputatų nebuvimas, nuolatinis Sąjūdžio kišimasis ị AT darbą. Todèl, iš esmès nepasisakydamas prieš pertvarkas ir Sajūdị, J. Baltušis laukè iš jo lyderių didelio draugiškumo ir tolerancijos visiems, kad jų gera valia tarnautų bendram pertvarkos labui [29, 3]. Kiek vèliau J. Baltušis laikèsi nuomonès, kad daug Lietuvos gyventojų, patikèję Sąjūdžio lyderiais, nesusigaudè, jog dauguma jų - karjeristai, kuriems rūpi asmeniniai siekiai ir interesai, „jie stumia mūsų tautą í aklavietę, nelaimèn“ $[10,209]$.

Tokia J. Baltušio pozicija sulaukė labai aštrios Sąūdžio lyderio V. Landsbergio kritikos televizijos laidoje „Atgimimo banga“. Pritardama Sąjūdžio lyderio nuomonei, literatūrologè Vanda Zaborskaite, priminusi J. Baltušio rašytojo talentą, vis dèlto kvietė visuomenę giliau apmąstyti ir geriau pažinti žmones ir situacijas, o ne pasitenkinti nepriimtino asmens, šiuo atveju J. Baltušio, karštakošišku atstūmimu ir niekinimu [31,4]. Profesorès raginimai atsimuše kaip žirniai i sieną. Tuo metu vieša Sąūdžio kritika reiškẻ tautos įžeidimą. Taip atsitiko ir J. Baltušiui, kuris užsitraukè visuomenès neapykantą, kai $1990 \mathrm{~m}$. balandžio $1 \mathrm{~d}$. Maskvos televizijos laidoje „Vremia“ („Laikas“) pareiškè: „Mums reikia ịsisąmoninti vieną tiesą: be rusų tautos, be kitų Tarybų Sąungos tautų, atsiskyrusi Lietuva negalès gyvuoti. Aš nematau kito kelio. Ir jeigu gerai pagalvosite, jūs suvoksite šitą neginčijamą tiesą. Tiktai kartu su visomis tautoms, draugiškai, vieningai, tiktai federacijoje mes galime siekti tautos savarankiškumo, savimonès, tikros demokratijos, kurios dabar Lietuvoje nèra - jūs patys žinote“ [10, 208-209]. Balandžio 7 d. LKP laikraštyje Tarybu Lietuva išspausdintame straipsnyje „Juozas Baltušis: Tiktai drauge!“ nurodyta, kad tai buvo šio rašytojo interviu programai „Vremia“. 
Šioje istorijoje svarbiausia yra tai, kad iš tiesų J. Baltušis nei programai „Vremia“, nei laikraščiui Tarybų Lietuva nedavė interviu. Davè saviems - Lietuvos televizijos rusų redakcijai, kuri be rašytojo leidimo interviu persiuntė Maskvai. Taip rašytojas buvęs apgautas, o Lietuvos televizija žodžio J. Baltušiui nesuteikè. İsižeidęs J. Baltušis atsisakè važiuoti ị Maskvoje vykusị SSKP XXVIII suvažiavimą, atsisakè stoti ị atsiskyrusią promaskvietišką LKP [10, 209-210, 213]. To plačiajai visuomenei nepaaiškinus, J. Baltušis viešai pradètas vadinti „Maskvos tarnu“ $[27,2]$, nepagarbiai elgtasi su šio rašytojo išleistomis knygomis. Net Rašytojų sajungos pastate ant palangès buvo galima rasti išdèliotų J. Baltušio knygų su pataisytu autoriaus vardu - Judas ir užrašu: „Iš pradžių vasaras pardavinejjo, o dabar Lietuvą pardavë“ [5, 3]. Dar neseniai buvę ištikimi J. Baltušio skaitytojai plěšè ir degino jo knygas [24, 5], nešė jas prie J. Baltušio namų durų, smerkè už kitokią nei daugumos nuomonę, iš rašytojo atimtas Anykščių rajono garbės piliečio vardas. Buvo pakeistas net J. Baltušio namų telefono numeris, nes „šlykščiausi skambučiai trukdydavo visą parą" $[23,1988]$. Kaip taikliai pažymėjo pasmerkto rašytojo dukra Rita Baltušytè, „per vieną dieną tūkstančiai ištikimiausių jo gerbejjų tapo jeigu ne rūsčiais teisèjais, tai bent nuoširdžiai pasipiktinusiais ir skaudžiai apviltais žmonėmis. Griežtai smerkiantys laiškai ir pasisakymai, vinimi perkaltos ar kitaip išniekintos rašytojo knygos, o iš mokyklų programų ištrinta rašytojo pavardè, - toks buvo nuosprendis“ [11, 7].

Vykstant masiniam puolimui prieš J. Baltušį, nuo jo nusisuko ir kolegos rašytojai, Lietuvos rašytojų sąunga, vadovaujama V. Martinkaus. LRS valdyba posėdyje prièmé nutarimą „griežtai atsiriboti nuo Baltušio dèl jo minčių apie Lietuvos nepriklausomybę " [11, 262]. Vis dèlto LRS nedrịso imtis pačios griežčiausios sankcijos - pašalinti J. Baltušį iš sąjungos. Nors tokių raginimų sulaukta pirmiausia iš pačių rašytojų, LRS vadovybė tam užkirto kelią [2, 29-30, 32-33]. 1994 m. LRS visuotiniame suvažiavime priminus, kad „valdyba ne kartą rimtai tarèsi ir audringai ginčijosi dèl siūlymų „valyti“ organizaciją, palikti ar šalinti kai kuriuos jos narius“, nurodyta, kad „paskutinio teisèjo vaidmens neprisièmème“ $[1,124]$. Taigi J. Baltušis liko sajungos nariu, o jam mirus su juo buvo galima atsisveikinti Rašytojų sąjungos salèje (atsisveikinti su velioniu atejo daug žmonių, tarp jų - A. Brazauskas su vainiku; pagarbą parodè ir M. Burokevičius) [23, 1988].

Tiesa, kai kurie rašytojai ragino pagarbiau elgtis su garbaus amžiaus sulaukusiu J. Baltušiu. Šiaurès Atènų redaktorius S. Šaltenis, pripažinęs, kad tikrai neketina ginčytis su garbingo amžiaus kolega, kreipèsi ị Sąjūdị, kad šis dèl visa ko paprašytų nusivylusius J. Baltušiu skaitytojus nemėtyti, nenaikinti jo knygų (apie tai Sąūdžio lyderis Vytautas Landsbergis kalbejjo per televiziją). Be to, S. Šaltenis labai prašè visų Šiaurès Atėnu skaitytojų neužversti rašytojo laiptinès jo raštais, neskambinti jam be jokio reikalo telefonu: „Liaukitès siuntinėję rašytojui knygas paštu, nes juk jis jau yra tikrai skaitęs nuosavas knygas! Praeis metai, kiti, nubrauksim dulkes nuo viršelių su draugo Baltušio pavarde (jei dabar nesinori ị rašytojo raštus žiūrèt) ir pasidžiaugsim, kad turim ne tik akmenį Puntuką ar velnių muziejų, bet ir garsų skandalingą rašytoją, saugotiną valstybės bei partijos bendražygių. Pagaliau juk dažniausiai rašytojas ir knyga būna visiškai nepanašūs dalykai, retai kas gyvena taip, kaip ir rašo..." [28, 2].

J. Baltušis, labai emocingai išgyvendamas savo pasmerkimą (Laimonas Noreika atsiminimuose aprašo susitikimą su rašytoju: „Aha, sąjūdininkas, o aš tai ne; o kai reikejjo pasirašyti raštą, smerkiantị Pasternaką, tai aš atsisakiau, - čia, aišku, ne sąjūdis. O atkovoti, kad nebūtų naikinamos kapinès - tai ne sajūdis, o ant Tumo-Vaižganto tilto atstatyti Vaižganto bareljefai - tai ne sąjūdis, o sekretorių CK spaudimo atlaikymas - tai ne sąjūdis. O Jono Jurašo globojimas - aš dalyvavau jo vestuvèse Aušros vartuose ir išlydejjau ji i t užsienį, kada kiti bijojo prie jo prieiti - tai ne sąjūdis. J. Baltušis karščiuojasi, beveik šaukia. Aš imu ji už 
pečių, kratau ir sakau: nurimkit, taip negalima jaudintis, o Baltušis: aš jaudinuos, aš jaudinuos? Ne taip greit mane sujaudinsit. Monika [antroji J. Baltušio žmona Monika Mironaitė (1913-2000) - M. T.] rẻkia: Juozai, išeik, mums su Laimonu reikia pasikalbėti. J. Baltušis išeina, bet tučtuojau grịžta su laikraščiais ir pasipiktinęs skaito kažkokias charakteristikas apie save.“) [23, 184-185], jautèsi teisus ir laiške anūkei Akvilei rašè, kad „tuo tarpu mano atžvilgiu girdèjau tiktai prakeiksmus ir grasinimus, be jokių ỉrodinėjimų ir ginčų “ $[10,212]$, o 1990 m. liepos pradžioje seseriai Marytei pripažino, kad jo „persekiojimai“ susilpnèjo, šiek tiek atleista ekonominẻ blokada, laukiama derybų su Maskva, žmonės, turèdami kitų interesų, tuo ir užsiima, „vis daugiau žmonių dabar mato, jog buvau teisus aš, o ne kas kiekviename žingsnyje šaukè apie savo meilę Lietuvai“. J. Baltušis visiems jiems linkėjo Dievo pagalbos, jokios rūstybès jų adresu nejautė $[11,233]$.

Kaip rodo išlikę šaltiniai, J. Baltušį laikyti komunistu-stalinistu būtų netikslinga. Jis atgimimo laikotarpiu pasmerkè stalinizmo metais vykusias represijas [10, 207], už 1988 m. Pergalès Nr. 8 ir 9 išspausdinto kūrinio Sakmé apie Juza ištraukas gautą honorarą paskyre paminklui stalinizmo aukoms statyti. Galiausiai J. Baltušis palankiai vertino Lietuvoje ir SSRS pradètus pertvarkymus, ypač gerokai didesnę žodžio ir spaudos laisvę. Rašytojas laikėsi nuomonės, kad bėgant laikui gyvenimas gerės. Tačiau J. Baltušis savo podukrai Dangei (Jakševičiūtè-Jefremovienè su vyru buvo sąjūdiečiai) sakydavo, kad jis netiki žmonių vieningumu, buvo tos nuomonès, kad Sąjūdis bus greitai išduotas ir sunaikintas, jis nesąs prieš Lietuvos nepriklausomybę, bet buvo įsitikinęs, kad tokiam žingsniui per anksti - negi „KGB taip lengvai paleis iš savo nagų Lietuvą? Nebūkite naivūs!“ [10, 214].

Kita vertus, negalima teigti, kad J. Baltušis buvo kategoriškai nusistatęs prieš nepriklausomą Lietuvą (tiesa, jis to viešai nesakydavo, be to, neviešai išsakytą nuomonę keitè). 1990 m. viduryje seseriai adresuotame laiške J. Baltušis pripažino, kad yra už Lietuvos laisvę, bet už tokią Lietuvą, kuri iš tiesų būtų laisva, kurioje kiekvienas žmogus turètų teisę turèti savo nuomonę ir teisę tą nuomonę viešai išreikšti, kiekvienam žmogui būtų sudarytos sąlygos laisvai plètoti savo gebejjimus, savo talentą ir siekti kartu su visais Lietuvos piliečiais lietuvių tautos laimès, gerovès, kultūros. Rašytojas paneigè jam metamus kaltinimus, kad jis esąs prieš Lietuvos nepriklausomybę. „Tai - melas ir veidmainystė“ $[11,251]$. Kadangi šie žodžiai nebuvo paskelbti viešai, visuomenè toliau laikèsi griežtos pozicijos J. Baltušio atžvilgiu. „Paskutinis didysis pasakotojas, improvizuotojas su aktorystės kaimietišku meistriškumu balse ir akyse. $<\ldots>$ Baltušis - vienas spalvingiausių personažų, o jo liežuvio aštrumas negula ị istoriografiją, nors pasiusk - negula" [8, 63-64]. Vytautas Martinkus, sužinojęs apie silpstantị J. Baltušį, pasitaręs su monsinjoru Kazimieru Vasiliausku, 1991 m. sausio 30-ąją kartu aplankè ji ligoninèje (Antakalnyje). V. Martinkui nepavyko sužinoti, apie ką ligonis ir dvasininkas kalbejosi, o su V. Martinkumi palietęs jam itin skaudžią temą J. Baltušis tik ištarè: „Nesu prieš Lietuvą“ $[14,15]$.

Audra dèl Parduotu vasaru autoriaus nesibaigè ir jam iškeliavus Anapilin (1991 m. vasario 4 d.). Pirmiausia nebuvo išpildyta velionio paskutinė valia - būti palaidotam Svèdasuose, šalia savo tèvo. Tam pasipriešino Svèdasų sąūdžio iniciatyvinè grupe (jos supratimu, neleis niekinti šventos žemès), o LR AT neleido rašytojo palaidoti Vilniuje, Antakalnio kapinèse, Menininkų kalnelyje, kur palaidoti Lietuvai nusipelnę asmenys. Nors velionis ir buvo palaidotas šiose kapinèse, bet ne minètame kalnelyje, o nuošaliau. Nepaisant anksčiau minètų viešų J. Baltušio pasmerkimų, rašytojo laidotuvėse dalyvavo didelis būrys jo kūrybos gerbejų. LRS pirmininkas V. Martinkus, neprimindamas prieštaringų paskutiniųjų metų velionio politinių pareiškimų ir palankiai atsiliepdamas apie J. Baltušio kūrybą, pažymèjo, 
kad „literatūra kaip menas yra vertingesnè ir ilgaamžiškesnè už pasalūnišką charakterio klastą, už politines audras bei politikierių rietenas, už susikrautus žemiškuosius turtus bei nomenklatūrinių pareigų piramides" $[15,7]$. Kiek objektyvesnị J. Baltušio ịvertinimą spaudoje pateikè P. Bražènas: „ > ..> išèjo menininkas ir žmogus, savo gyvenimu ir kūryba nusipelnęs bei susilaukęs tokio dèmesio, tokių prieštaringų vertinimų, tokių spontaniškų savo gerbejjų bei oponentų jausmų proveržių, tokių pagarbos ir nusivylimo, net neapykantos ženklų, kuriuos bet kuriuo kitu atveju tiesiog sunku būtų susieti su vienu žmogumi. Išèjo viena spalvingiausių, prieštaringiausių, o gal ir mįslingiausių asmenybių, palikusi nevienaprasmius pėdsakus daugelio pažinojusiųjų širdyse, ir talentingiausių savo kartos rašytojų, kurio kūryba ne tik paliudijo lietuviško meninio žodžio galias, bet ir neišvengè daugelio neišdildomų randų, paliktų negailestingo laiko" [6, 3].

Kaip matome, apsiribota gana švelniu J. Baltušio apibūdinimu. Tačiau tai nereiškè, kad mirtis sudèjo visus taškus ant „“"vertinant šią asmenybę. Požiūris ị jị ir šiais laikais išlieka labai prieštaringas, sakyčiau, labiau neigiamas (bene labiausiai J. Baltušs mègina reabilituoti jo giminaičiai) (3). Kadaise Šiaurès Atènu redaktoriaus S. Šaltenis J. Baltuši palygino su garsiuoju Norvegijos rašytoju, Nobelio premijos laureatu Knutu Hamsunu (4), sakydamas: „Išties, kai pagalvoji, kuo mes blogesni už skandinavus, kurie turi pasaulinio garso rašytoją Knutą Hamsuną, karo laikų kolaborantą, nežinia kaip sugebejusị įžvelgti Hitlerio politikoj Europos atgimimą [pasibaigus Antrajam pasauliniam karui rašytojas K. Hamsunas prieš savo valią buvo uždarytas ì psichiatrinę ligoninę, jo kūryba keliems dešimtmečiams uždrausta, knygas imta viešai deginti - M. T.]. Mes irgi turim teisę turèti savąji - tegul ne tokio talento, tegul ne pasaulinį milžiną, bet irgi nuosavą rašytoją kolaborantą “. Iš tiesų J. Baltušị sąlyginai galima gretinti su K. Hamsunu, nors abu rašytojai veikė skirtingais laikotarpiais: lietuvis savo poziciją išreiškè „dainuojančios revoliucijos“ metu, kai buvo galima viešai pasakyti ịvairią nuomonę svarbiais klausimais; norvegas veikè sudėtingais Antrojo pasaulinio karo ir pokario metais, kai Norvegijos, kaip ir daugumos kitų Europos valstybių, gyventojai, skaudžiai išgyvendami tragiškus netolimos praeities įvykius, siekė suvesti sąskaitas su savo nusikaltusiais tautiečiais (tuo metu daugiausia teisiami su naciais kolaboravę asmenys). Tačiau esama daug panašumo tarp J. Baltušio ir K. Hamsuno, kurị pirmasis nuo jaunystès laikų tiesiog dievino. Taigi:

- Abu sulaukę jau garbingo amžiaus užsitraukè dalies savo šalies gyventojų neapykantą: lietuvių rašytojas Lietuvos valstybės gyvenimą siejo su SSRS, o norvegų rašytojas okupuotos Norvegijos likimą - su nacistine Vokietija. Paradoksas, tačiau J. Baltušis gyvenimo pabaigoje pripažino, kad jis kadaise labai išgyveno dèl K. Hamsuno: „O kai jis padarè tą klaidą - Hitlerio politikai pritarè, norvegai pokario metais pradėjo grąžinti jam knygas, tūkstančių tūkstančius, visą sodybą, visus privažiavimus užvertė jo knygomis...<..> Taip mylëjau Hamsuną, taip išgyvenau tą jo klaidą, kad bijojau imti ị rankas jo dvitomị, bijojau, kad jo jau nebemylèsiu. Literatūra irgi sensta: susižavi šimtai tūkstančių, o po to atsiverti - nesiskaito, ir gana. Man buvo didelè laimè, kai atsiverčiau, o Hamsunas buvo ir liko ne vienas mylimiausių, bet pats mylimiausias mano rašytojas“ [11, 328].

(3) Bene geriausias pavyzdys prieš kelerius metus pasirodžiusi D. Jakševičiūtès knyga [10]; J. Baltušis - laiko audrų blaškytas rašytojas. Prieiga per internetą: http://www.bernardinai.lt/ straipsnis/2006-02-08-j-baltusis-laiko-audru-blaskytas-rasytojas/5508 [žr. 201511 04].

(4) Išsamią šio rašytojo biografiją žr.: Kolloen I. S. Hamsunas: svajotojas ir užkariautojas. Vilnius, 2013. 
- Savo „nusikalstamos“ veiklos metu dèl senatvès ir J. Baltušis, ir K. Hamsunas turèjo didelių sveikatos problemų, todèl ne visada sugebẻdavo adekvačiai reaguoti ị jų šalyse vykstančius politinius įvykius (J. Baltušis 1990 m. kovo 26 d. laiške savo dukrai rašè: „Gyvenimas Lietuvoje kiek maištingas, kupinas ịvykių, pakitimų, nebe viską spejju sekti, manau, kad šito nè nereikia. Viskas eina, kaip sakoma, savo keliu, nors man, tokio amželio sulaukusiam, ne visuomet ir viskas aišku“.) [11, 247]; K. Hamsunas buvo beveik aklas.

- J. Baltušis tautinio atgimimo metais, o K. Hamsunas Antrojo pasaulinio karo metais, būdami rašytojai, neužèmè svarbių politinių postų, o jiems primetamus „nusikaltimus" padarè savo poziciją pareikšdami žiniasklaidoje ar pasakytomis kalbomis. Jie abu nepasirašinėjo juridinių ịstatymų, nuo kurių priklausė daugelio jų tautiečių likimai, dažnai pasibaigę tragiškai. Todèl J. Baltušio veiklos poveikis savo tautiečiams tautinio atgimimo ir K. Hamsuno Antrojo pasaulinio karo metais yra ne toks jau didelis ar toks jau nusikalstamas kaip, tarkime, Mykolo Burokevičiaus, Juozo Jarmalavičiaus, Juozo Kuolelio - tragiškųjų 1991 m. sausio 13 d. įvykių svarbių veikejjų ar Vidkūno Kvislingo - Norvegijos pronacistinès vyriausybès vadovo, nuo kurio sprendimų tiesiogiai nukentejo dauguma norvegų.

- Abu iki gyvenimo pabaigos viešai gynè savo užimtas pozicijas ir neketino jų išsižadèti. J. Baltušis taip ir liko Lietuvos SSRS sudètyje šalininku, t. y. jis viešai neatsisake savo žodžių, nepareiškè, kad jo samprotavimai buvę klaidingi. Anot Romo Gudaičio, „mums - žlunga okupacija, Baltušiui - darbo žmonių valdžia, ir kaip išdrịsti jam pasakyti, kad tiki fikcija!“ [8, 64]. 1990 m. rugsejjo 14 d. laiške savo dukrai Ritai J. Baltušis pareiškė: „Daugiau ir daugiau žmonių Lietuvoje pradeda suprasti, kad mano nuomoné, pasakyta per Maskvos televiziją, buvo teisinga ir pagrịsta. Atvirai kalbant, nė vieno žodžio, ištarto mano kalbose, tiek paminètoje, tiek ir kitose, aš neatšaukiu ir neatsisakau nė vieno jų. Esu ịsitikinęs, kad ir aš turiu pilną teisę turèti savo nuomonę ir ją viešai išsakyti. Kaip ir visi kiti pasaulio žmonès. Ir, priešingai, neturiu teisès tylèti, kai matau, $\mathfrak{i}$ kokius naujus ir naujus sunkumus stumiama Lietuva. Ir jeigu aš klystu, tai juk, kaip man atrodo, galima pabandyti sukritikuoti mane, užginčyti mano skelbiamas mintis, įrodyti jų neteisingumą. Kaip ir daroma kultūringoje, demokratinèje visuomenèje. Tuo tarpu mano atžvilgiu girdejjau tiktai prakeikimus ir grasinimus, be jokių ịrodinejjimų ir ginčų. Iš to irgi darau išvadą, jog iš tikrųjų buvau teisus" [11, 236]. K. Hamsunas 1946 m. liepos 23 d. valstybès prokurorui adresuotame laiške nurodè, kad „vienas vienintelis dalykas, parbloškiantis mane žemyn, yra mano straipsniai laikraščiuose. $\langle\ldots>$ Aš nebandau sumažinti jų reikšmès, sakyti, kad klydau. Priešingai - aš ir anksčiau, ir dabar nesigėdiju jų, laikau teisingais. $<\ldots>$ Aš rašiau apie Norvegiją, kuri privalèjo gauti deramą vietą tarp kitų germanų kraštų Europoje. Turètų būti sąžiningai suprasta, kodèl aš panašiai rašiau apie okupacinę valdžią. Aš visąlaik buvau supamas vokiečių karininkų ir paprastų kareivių savo name, net naktimis, taip, daug kartų ir naktimis, iki ryto šviesos. Ir kartkartėmis man kildavo ịspūdis, kad esu apsuptas stebėtojų, žmonių, kurie gavę užduotị kontroliuoti mane, mano veiklą" $[9,139-140]$. Tiesa, K. Hamsunui pokariu buvo iškelta byla. Nors dèl literatūrinių pasiekimų ir garbaus amžiaus (86 metai) iš pradžių jis buvo apgyvendintas senelių prieglaudoje, paskui kurị laiką psichiatrinèje ligoninèje, tačiau atkakliai pasipriešinus pačiam rašytojui, ịvyko $K$. Hamsuno teismas, kuris prièmé sprendimą, kad rašytojas dẻl padarytos žalos savo šaliai privalo sumokèti 325 tūkst. kronų (rašytojas savo mirtimi mirè sulaukęs 92 metų).

- J. Baltušio kūriniai Lietuvoje, o ypač K. Hamsuno Norvegijoje, kurị laiką buvo tabu (ịvairiais būdais naikinamos jų knygos; uždrausta jas skaityti) ir tik praejjus keliems 
dešimtmečiams norvegai atsipeikèjo ir visuomenè vèl èmè rodyti pagarbą K. Hamsuno kūrybai. Belieka viltis, kad ir Lietuvoje pamažu prasidès J. Baltušio kūrinių reabilitacija.

\section{„NEREIKALINGAS ŽMOGUS": EDUARDAS MIEŽELAITIS}

Eduardas Mieželaitis (1919-1997) savo poziciją tautinio atgimimo metais Lietuvos persitvarkymo sąūuž̌io nariui rašytojui Georgijui Jefremovui išdèste šiais žodžiais: „Daug pas jus ten šlamšto, daug kas ir reikalinga, bet niekas dabar nebe mano. Aš komandos jau nekeisiu. $\langle\ldots\rangle$ Kiekvienoje epochoje savi praregèjimai ir klystkeliai. Aš pirmenybę teikiu tam, ką geriausia mačiau ir patyriau. $\mathrm{O}$ ir nepriims manęs tie naujieji..." $[21,233$. Poetas neịstojo ị Sąjūdį ne todèl, kad būtų abejojęs kuriuo nors jo programos teiginiu, o todèl, kad nepasitikejjo kai kuriais šio judejjimo dalyviais: „Netikiu jais, - kalbejo. - Ir jūs jais netikèkite. Žinau šių žmonių praeiti, žinau, kuo jie buvo ir ką gali padaryti“ $[21,175]$. Todèl tuometinis LSSR AT deputatas, AT prezidiumo pirmininko pavaduotojas E. Mieželaitis (Sigitą Gedą traukẻ pati E. Mieželaičio laikysena - „išdidaus, oraus, aristokratiško žmogaus poeto. Vidujai laisvo“) [21, 225] nedalyvavo Sąjūdžio mitinguose (rašytojo Vacio Reimerio teigimu, E. Mieželaitis, pritardamas Sąjūdžio bangai, „protu negalèjo susitaikyti, kad ideologinių dvasinių vertybių revizija taip skaudžiai palies jị “) [21,300] ir ì permainas žvelgè iš atokiau. Jis nenorẻjo (ar neįstengè) peržengti ribos, skyrusios senąji sovietinị pasaulị ir kuriamą naująji . Būdamas garbingo amžiaus E. Mieželaitis turẻjo savitą požiūrị i i šalyje vykstančias permainas. Antai 1989 m. pavasarị kartu su Justinu Marcinkevičiumi visuomeninių organizacijų išrinktas SSRS liaudies deputatu $[12,4]$ (ị SSRS Liaudies suvažiavimą, nurungus kitus kandidatus, buvo išrinkti šie Sąjūdžio remiami kandidatai rašytojai: Sigitas Gedas, Romas Gudaitis, Marcelijus Martinaitis, Stasys Kašauskas ir Jakovas (Grigorijus) Kanovičius [13, 8]) E. Mieželaitis savo laikysena Maskvoje išsiskyrė iš kitų Lietuvos deputatų. Marcelijus Martinaitis prisimena „keistą“ E. Mieželaičio elgesị SSRS liaudies deputatų suvažiavime: jis su lietuvių deputatais sąjūdininkais nesėdèjo, „buvo kažkoks atsiskyręs, nekalbus, lyg ir liūdnas, vienišas, pavargęs, neatsimenu, kad būtų ką nors kalbejęs, tikriausiai nieko mums ir nepakenkè. Prasidejus tiems suvažiavimams deputatus dar veike seni ịpročiai, sakysime, po kokios nors trafaretinès frazès ploti arba urmu visai salei stotis. Mes buvome sutarę to nedaryti, didžiulèje salëje likdavome maža sėdinčiųjų salelè, o mūsų pusėn iš pradžių skriedavo piktos replikos ar net grasinama, kol salè su tuo apsiprato, o kitų respublikų delegatai netrukus nustojo šokinėti iš savo vietų. Ir štai tada man labai ịstrigo E. Mieželaitis. Salè, pritardama kažkokiam kalbėtojui, užstojusiam Tbilisio represijų vykdytojus, kareiviškais kastuvèliais aikštėje talžiusius galvas, atsistojo, išskyrus gruzinus ir mus. Štai nuo tada E. Mieželaitis mano atmintyje taip ir liko stovintis tarp mūsų, rodos, tik su dviem jedinstvininkais [„Jedinstvo“ - tuo metu Lietuvoje veikęs prosovietinis judejjimas - M. T.]. Tada pagalvojau, štai kaip dabar atrodo tas jo išgarsintas, tarp žemės ir dangaus pastatytas Žmogus - vienišas, liūdnas, kažkoks paliegęs ar net pasimetęs, užkluptas greitų, netikètų permainų “ $[21,36-37]$. Tai paaiškina, kodèl E. Mieželaitis laikèsi nuošaly nuo Sąjūdžio ir tautinio atgimimo reikalų ir turẻjo savą požiūrị i Lietuvą po jos nepriklausomybès atkūrimo.

Sovietiniu laikotarpiu karjerą padariusiems rašytojams atgimimo ir pirmaisiais nepriklausomybès metais atèjo sunkūs laikai: puoselejjamos kitos vertybės, ị viešumą iškilo kiti kūrejjai, kurie nevengė atvirai kritikuoti komunistinei santvarkai tarnavusių rašytojų. Net bandyta juos sukompromituoti, siekta, kad viešai atgailautų dèl savo praeities kūrybos. E. Mieželaitis buvo pasipiktinęs nuožmia visuomenès kampanija prieš J. Baltušş [21, 301], poetui buvo skaudu, kai 1996 m. jam paskambinusi Lietuvos aido žurnalistė mégino išprovokuoti pokalbị, kuriame jis muštųsi ị krūtinę. Poeto įsitikinimu, to padaryti nepavykę, nes jis 
laikèsi nuomonès - Žmogus suvaidino progresyvų vaidmenị ir pasklido pasaulyje [16, 8]. Tuo metu senyvo amžiaus sulaukęs poetas, nors "nepuolè muštis ị krūtinę, atgailauti“ $[4,383]$, atsiribojo nuo bet kokios aktyvesnès visuomeninès, politinès veiklos [7, 4] ir jautėsi niekam nereikalingas. Tačiau nuo poeto nenorejo atsiriboti jo kolegos. Anot Valentino Sventicko, E. Mieželaitis „užmirštas, vienišas, nereikalingas... Ši būsena ịaitrinta, gal iš dalies susikurta. Bičiuliai, lankę ir kalbinę poetą iki jo saulèlydžio, paskaitę dienoraščius gūžtelèjo pečiais. Prisimenu, ne kartą kalbinęs poetą pasirodyti, paskaityti bent didžiuosiuose metų skaitymuose ir girdejęs įprastą atsakymą - gerai, spurdèkite, bet 'jau be manęs'“ [26, 149]. Dar atgimimo išvakarèse R. Gudaitis mėgino E. Mieželaiti ịtraukti i RS atvirus partinius susirinkimus, tačiau pastarasis išdidžiai atsisakè. Nepasidavė E. Mieželaitis ir Alfonso Maldonio ịkalbamas [8, 167]. Pasirinkta saviizoliacija, o įdomiausia tai, kad nepriklausomybės metais, kaip taikliai pažymëjo V. Sventickas, „E. Mieželaitis reflektavo ne tiek Lietuvos kitimų procesus, kiek savo išgyvenimus“ [26, 149]. Dienoraščiai liudija, kad „Nereikalingas žmogus“ skaudžiai išgyveno nepriklausomybès metais jị užgriuvusius buitinius sunkumus. Kartais poetą užvaldydavo toks didelis pesimizmas, kad nebelikdavo net noro toliau gyventi, pabrèžiamas vienišumas: „Išstumtas iš gyvenimo, likau vienas kaip pirštas ir vienišas kaip nakties paukštis..." Dèl pablogejjusios materialinès padèties E. Mieželaitis kaltino nepriklausomos Lietuvos valdžią: „Man sako - mylèk. Nebūkit, ponai, juokingi. Kaip aš galiu mylèti tą valdžią, kuri mane pavertè ubagu?"“ $[17,9]$. Pinigu jam nuolat reikèjo gydymuisi, susimokèti už komunalines paslaugas, tad tikejosi atgauti savo pinigus iš bankrutavusio banko (po didelio vargo pusę sumos atgavo, o pusę sumos paverte akcijomis). Poetas pyko dèl didelių komunalinių mokesčių, kuriuos sumokejus jam likdavo mažai pensijos („nedaug iš pensijos lieka maistui, nekalbant apie kitas būtinas prekes. Plěšikų, banditų, mafijozų apetitai!“) $[18,10]$. Ypač E. Mieželaičiui buvo skaudu, kai Kultūros ministerija atsisakè finansiškai paremti jo eilèraščių knygos leidimą ir kai kultūros ministras nesutiko padaryti išejusios knygos Mitai prezentacijos. Dèl to poetas jautèsi labai įžeistas ir dienoraštyje labai nepagarbiai atsiliepe apie tuometini ministrą, kurio pavardè nebuvo nurodyta (tuo metu kultūros ministro pareigas èjo rašytojas Saulius Šaltenis).

Net iš viešumos pasitraukęs $\mathrm{E}$. Mieželaitis negalejo gyventi nekurdamas poezijos (testamente rašè: „Didžiausia mano meilè buvo Poezija, riteriškai jai tarnavau, visa kita mano veikla tik balastas“ $[20,198])$. Tad ir nepriklausomybès metais stengèsi pagal galimybes savo laiką skirti kūrybai: „rašau ir toliau rašysiu, kol krūtinèje plaks širdis“ $[18,10]$. Pasirode net kelios poeto knygos, tačiau gauti už jas bent kiek padoresni atlygi autoriui nepavyko. Pavyzdžiui, išèjus Mitams, leidejas iš Kauno jam atvežè 20 knygos egzempliorių. Pinigų neème், bet ir honoraras minimalus. Pasitaikydavo ir tokių atvejų, kai leidykla honoraro paprasčiausiai nesumokèdavo $[18,10]$. O pinigu poetui labai reikèjo: „verčiuosi sunkiai, dabar vasara, reikètų kur nors išvažiuoti ir pailsèti nuo tos velniavos, bet nèra iš ko, trūksta pinigų. Jau šešeri metai, kai neišvažiuoju ị jokị kurortą $\langle\ldots$. . Taigi reikalingi pinigai, kurių nuolat neužtenka. <..>. I ką mus pavertè laukinis, žvėriškas kapitalizmas?" [17, 9]. Jam buvo pikta, kad pinigai nuvertėjo, kad už juos neįmanoma nieko nupirkti: „Nežinau, kaip reikès toliau gyventi - viskas brangsta, brangsta, brangsta, pinigas pinga, pinga, pinga - pinga ir žmogus. Lieka žmogui vienas vienintelis ir artimiausias kelias - po velèna. Ką tie išprotėję komersantai daro?“ $[18,10]$. E. Mieželaitis labai išgyveno dẻl itin mažos pensijos: „Buvau taupomajame banke, atsiemmiau savo kuklią pensiją ir pasidare taip graudu, jog norèjosi tik apsiverkti“ $[19,10]$. To nebuvo Lietuvos priklausomybės metais, kai E. Mieželaitis nuolat užimdavo ịvairias aukštas pareigas. O kur dar kitos lengvatos ir honorarai už didžiuliais tiražais leidžiamą kūrybą! „1967-1971 m. vien už lietuviškai publikuotus tekstus E. Mieželaičiui buvo 
išmokèta 78000 rublių honoraro, Marcinkevičiui - 64 000“ [25]; kai kurie rašytojai gaudavo ne ką mažesnius atlyginimus. E. Mieželaitis laikèsi zenite net keletą dešimtmečių, o dabar staiga, prasidejjus tautiniam atgimimui, viskas iš esmès pasikeitè. Dar visai neseni ịvykiai jau buvo istorija. Poetą ịskaudino ir tai, kad visos trys nepriklausomybès metais išleistos knygos nesulaukè jokio visuomenès dėmesio. Dèl to jautèsi niekam nereikalingas, įskaudintas, pamirštas, nes buvo ịpratęs „būti pirmam plane“ [21, 233]. Justo Vinco Paleckio teigimu, po nepriklausomybès atkūrimo poetą žeidè jo kūrybos nutylëjimas ir „užbraukimas“, užgaulios užuominos spaudoje. „Ir tai, kad tuometinè valdžia, jo manymu, nieko nedaro ar daro mažai, kad apgintų žmones, daug nuveikusius Lietuvai. Dar ir dabar ausyse skamba tuomet telefono ragelyje nuaidejjusi frazè, kai jis, kaip visad, lètai, svariai, bet susierzinęs pagiežingai ištarè: 'Jeigu nepadarysite to ir to (jau neprisimenu konkrečiai), aš parašysiu, aš viską išdèsiu, kaip buvo. Jums (suprask - esantiems valdžioje) bus riesta"“ [21, 97].

Nors buitinès sąlygos buvo sunkios, E. Mieželaitis iki pat gyvenimo pabaigos negalejjo be poezijos, vos tik sveikatai sustiprejus jis ketino toliau rašyti: „Ir aš turiu labai aktyvų narkotiką - poeziją“ $[17,9]$. Nieko keista, kad po poeto mirties dienos šviesą išvydo kelios knygos. Tačiau jị nuolat kankino abejonès: „Būti ar nebūti - štai kur klausimas, kuris pastaruoju metu vis dažniau ir man iškyla. Ar verta dar rašyti?" Nesant atsiliepimų apie išleistas knygas, kildavo dèsningas klausimas: ar jo kūryba bus kam nors reikalinga? („Ignoravimas tęsiamas - toks poetas neegzistuoja.“) Kildavo ir abejonių: „o kur visą tą rašliavą spausdinti ir kur išleisti knygą?" E. Mieželaičio supratimu, „cenzūra buvo tada ir liko dabar - tik tada buvo politinè cenzūra, o dabar tai ekonominè cenzūra. Jeigu tavo knyga bus pelninga kapitalistui leidejui, jis ją išleis, jeigu nuostolinga - jokiu būdu nerems ir neleis“ $[17,10]$. Štai tokios mintys kamavo E. Mieželaitị paskutiniais jo gyvavimo metais. To laikotarpio poeto būseną taikliai atspindi eilèraščio „Vienatvë“ žodžiai: „tyli visą naktị kurčias telefonas/ tai ir aš tyliu tarytum nebylys/ ar tarytum morge paliktas lavonas/ laukiu kol koks katafalkas čia atklys“ [22, 3].

Nors E. Mieželaitis tautinio atgimimo metais ir po nepriklausomybės atkūrimo neužrūstino visuomenès, nepasisakẻ prieš nepriklausomą Lietuvą (būdamas Lietuvos nepriklausomybès šalininkas 1993 m. dienoraštyje rašè: „Lietuvoje gimiau ir užaugau, Lietuva man visada buvo ir liko širdyje valstybė. Valstybė ji turètų išlikti ir ateityje“ $[21,198])$, vis dèlto net laidotuvių dieną neišvengta kuriozų. Pasak Vito Areškos, „viena moteriškė net spjovė priejusi prie kapo. Šiaip poetui buvo atiduota priderama pagarba, bet ore vis dèlto tvyrojo tam tikra įtampa ir nesutarimai, kaip vertinti poeto gyvenimą ir kūrybą" [21, 36-64]. Pats E. Mieželaitis tarsi išpranašavo savo mirtį ir jau nenorèjo gyventi. Likus pusmečiui iki mirties poetas dienoraštyje džiaugèsi, kad „gyvenimas jau eina ị pabaigą. Gal šie 1997-ieji bus man paskutiniai metai?“ $[19,10]$ Tokių minčių slegiamas tų metų birželio $6 \mathrm{~d}$. E. Mieželaitis iškeliavo Anapilin.

Išèjo vienas žymiausių LSSR poetų, kurio prieš kelis dešimtmečius sukurtas eilèraščiu ciklas Žmogus sudrebino tuometinès SSRS literatūrinị gyvenimą, o kartu suteikė galimybę kitiems sovietinejje aplinkoje gyvenantiems poetams ieškoti kūryboje naujų formų, nebijoti eksperimentuoti [8, 167]. Belieka pridurti, kad pasikeitusiomis sąlygomis Žmogaus autorius, save ịvardijęs „nereikalingu“ ir atsisakęs toliau dalyvauti nepriklausomos Lietuvos literatūriniame gyvenime, pats save atskyrė nuo jo ir visuomenès akyse liko penkiasdešimtmeti Lietuvoje gyvavusios sovietinès lietuvių literatūros kūrèju. Tai žmogus, nesugebejjęs (veikiau - nenorèjęs, priešingai nei Justinas Marcinkevičius) pabandyti savo kūryba ir visuomenine-politine veikla sujungti skirtingas epochas ir dèl to dèsningai pasilikęs nepriklausomos Lietuvos literatūrinio ir apskritai kultūrinio gyvenimo paraštėje. Taigi „jis neišsigynè 
epochos, kurios negalejo pats pasirinkti - jis net neatsisveikino su tais, kurie dabar apsimetė toje epochoje negyvenę, o tik ilgèjęsi laisvès ir naujųjų laikų " $[8,169]$.

\section{IŠVADOS}

1. Rašytojo J. Baltušio tautinio atgimimo laikotarpiu viešai išdėstytas kritiškas požiūris ị Lietuvos nepriklausomybès atkūrimą lèmè, kad šis sovietų lietuvių literatūros klasikas staiga tapo nemėgstamas daugumos lietuvių. Aprašyta J. Baltušio „prakeiksmo istorija“ tik patvirtina, kad nagrinèjant garsių rašytojų veiklą būtina atskirti jų kūrybą nuo politinès ar visuomeninès veiklos. Kitu atveju genialūs rašytojai dẻl vieno neatsakingo poelgio ilgam laikui bus pasmerkti, tas pats ištiks ir jų kūrybą. Tuomet atsivertų didelè kūrybinè tuštuma.

2. Poeto E. Mieželaičio atsiribojimas nuo bet kokios visuomeninès ir politinès veiklos tautinio atgimimo ir pirmaisiais nepriklausomybès metais, atsiradęs pesimizmas dèl savo pasunkèjusios buities ir kūrybos sąlygų, savęs laikymas niekam nereikalingu, neịvertintu žmogumi, leidžia teigti, kad ši asmenybẻ labai nusivylè ne tiek atkurta nepriklausoma Lietuva, kiek jos valdžia ir pasunkejjusiu ekonominiu žmonių (visų pirma savo paties) gyvenimu. Tai sovietmečiu „ant rankų“ nešioto, o pasikeitusiomis sąlygomis įžeisto žmogaus nenorejjimas susitaikyti su tuo, kad prarasto populiarumo, turètos įtakos ir svorio visuomenejje jau niekada nepavyks susigrąžinti.

Gauta 20151109

Priimta 20160321

\section{Šaltiniai ir literatūra}

[1] Lietuvos rašytojų sąjungos suvažiavimo stenograma, Vilnius, $1994 \mathrm{~m}$. gruodžio mèn. $16 \mathrm{~d}$. LLMA, f. 750, ap. 1, b. 35, 1. 124.

[2] Lietuvos rašytojų sąjungos visuotinio susirinkimo stenograma, 1992 m. sausio 6 d. LLMA, f. 750, ap. 1, b. 14, 1. 29-30, 32-33.

[3] AREŠKA, Vitas. Kumelè vardu Emilja: prisiminimai ir apmąstymai. Vilnius, 2007.

[4] BALTAKIS, Algimantas. Gimiau pačiu laiku: iš dienoraščių, 1960-1997. Vilnius, 2008.

[5] Baltušis pasiliko ištikimas Maskvai. Akiračiai, 1990, Nr. 5, p. 3.

[6] BRAŽĖNAS, Petras. Atsisveikinant su J. Baltušiu. Tiesa, 1991 vasario 5, p. 3.

[7] Eduardas Mieželaitis: „Ramybè skamba...“. Depolizuotas lapkričio pašnekesys su poetu Eduardu Mieželaičiu. Tiesa, 1992 lapkričio 7, p. 4.

[8] GUDAITIS, Romas. Piemuo norèjo Hamletu būti. Vilnius, 2013.

[9] HAMSUNAS, Knutas. Užžélusiais takais. Kaunas, 2001.

[10] JAKŠEVIČIŪTĖ, Dagnè. Gyvenom socializme: prisiminimai apie Juozą Baltušǐ. Vilnius, 2013.

[11] Juozas Baltušis iš arti: laiškai ir kt. Vilnius, 2010.

[12] Lietuvos atstovai, TSRS liaudies deputatai nuo visuomeninių organizacijų. Tiesa, 1989 kovo 29, p. 4.

[13] LKP rinkimų štabas. TSRS liaudies deputatų rinkimus laimejjo šie Sąjūdžio remiami kandidatai. Atgimimas, 1989, Nr. 10, p. 8.6.

[14] MARTINKUS, Vytautas. Kupiškio sakmè. Iš: Baltušis J. Sakmė apie Juzą. Vilnius, 2007, p. 5-16.

[15] MARTINKUS, Vytautas. Palydint Juozą Baltušį. Literatūra ir menas, 1991 vasario 9, p. 7.

[16] MIEŽELAITIS, Eduardas. Dvasinè alegorija. Dienoraštis. Šiaurès Atènai, 1999, Nr. 38, p. 8-9.

[17] MIEŽELAITIS, Eduardas. Dvasinè elegorija. Dienoraštis. Šiaurés Atėnai, 1999, Nr. 39, p. 10.

[18] MIEŽELAITIS, Eduardas. Dvasinè elegorija. Dienoraštis. Šiaurès Atènai, 1999, Nr. 44, p. 10.

[19] MIEŽELAITIS, Eduardas. Dvasinè elegorija. Dienoraštis. Šiaurès Aténai, 1999, Nr. 45, p. 10. 
[20] MIEŽELAITIS, Eduardas. Nereikalingas žmogus. Akcentai: autobiografinè esė. Vilnius, 2003.

[21] MIEŽELAITIS, Eduardas. Post scriptum. Prisiminimai apie Eduardą Mieželaiti, straipsniai, laiškai. Vilnius, 2008.

[22] MIEŽELAITIS, Eduardas. Vienatvè. Opozicija, 1993, Nr. 19, p. 3.

[23] NOREIKA, Laimonas. Vidurnakčio užrašai. Vilnius, 2001.

[24] SAVIČIENĖ, F. Šiukšliadežèse dega „Juza“, o rašytojo širdyje žėrèjo kaitrūs tarybinès idilès laužai... [apie rašytoją]. Europa, 1996, Nr. 25, p. 3.

[25] STREIKUS, Arūnas. Kitokio požiūrio ị Just. Marcinkevičių teks palaukti. Prieiga per internetą: http://www.delfi.lt/news/ringas/lit/a-streikus-kitokio-poziurio-i-just-marcinkeviciu-teks-palaukti.d?id=69405628 [žr. 20151103 ].

[26] SVENTICKAS, Valentinas. Reikalinga knyga. Iš: Mieželaitis E. Nereikalingas žmogus. Akcentai: autobiografinè esè. Vilnius, 2003, p. 151.

[27] ŠAKNYS, Bernardas. Rašytojo Baltušio nèra, tèra drg. Baltušis - Maskvos tarnas, TSKP narys: Atviras laiškas J. Baltušiui. Lietuvos aidas, 1990 birželio 13, p. 2.

[28] ŠALTENIS, Saulius. Jūsų daug - Baltušis vienas! Šiaurès Atènai, 1990, Nr. 17, p. 2.

[29] Vienuoliktojo šaukimo Lietuvos TSR Aukščiausiosios Tarybos tryliktoji sesija. Diskusijos dèl pranešimo apie politinę padètį Respublikoje. Tiesa, 1989 rugsèjo 26, p. 3.

[30] Vienuoliktojo šaukimo Lietuvos TSR Aukščiausiosios Tarybos dešimtoji sesija. Tiesa, 1988 lapkričio 25, p. 2-3.

[31] ZABORSKAITE், Vanda. Kaip reaguojame? Tiesa, 1989 spalio 4, p. 4.

MINDAUGAS TAMOŠAITIS

\section{Juozas Baltušis and Eduardas Mieželaitis during the National Revival and the first years of Lithuanian Independence}

Summary

The names of Juozas Baltušis (1909-1991) and Eduardas Mieželaitis (1919-1997) are inseparable from the Soviet Lithuanian literature. The first writer is famous for his widely known writings "Gieda gaideliai", "Parduotos vasaros", "Su kuo valgyta druska", "Sakme apie Juzą", etc. The second one published numerous poetry books and became famous in 1962 after he had received a notable Lenin's award for the cycle of poems "Human". Both writers were members of the Communist Party and held political office. They were the part of Soviet Lithuanian political elite.

A complicated period of life to both writers came during the National Revival and the first years of Lithuanian Independence. At that time the Lithuanian society got free from the Communist regime and the political situation has changed in the country. In the context of National Revival Eduardas Mieželaitis characterized himself as "unwelcome, needless person". Juozas Baltušis was severally criticized because he spoke out against the restoration of Lithuanian Independence.

The article aims to analyze the attitudes of Juozas Baltušis and Eduardas Mieželaitis towards the Lithuanian National Revival and the Lithuanian Independence restoration idea. The main task of this article includes the estimation of Juozas Baltušis' actions and society's reaction concerning his speeches and position 
towards the Lithuanian Independence. Furthermore, Eduardas Mieželaitis' attitude towards the events of the late 1980's in Lithuania is revealed.

The author of the article made the conclusion that Juozas Baltušis' critical attitude towards the Lithuanian secession from USSR in 1990 made him unpopular in the society. Juozas Baltušis' case reminds us that writer's political and literary activities and achievements have to be separated. Otherwise one or several reckless political actions made by the writer can condemn him and his literary work for a long time. Eduardas Mieželaitis' self-isolation from public activities during the National Revival and the first years of Independence and his pessimistic attitude towards new political conditions were determined by the change of his living conditions. Eduardas Mieželaitis was pessimistic about the economic downturn but not about the restoration of Lithuanian Independence. He was glorified as a writer during the Soviet era and lost his popularity after Lithuania became an independent state. He was disappointed by the reality and the idea that his "weight" in the society is weakened.

Keywords: J. Baltušis, E. Mieželaitis, Communist Party, National Revival, Sąjūdis, Lithuanian Independence, government, opposition 